\title{
Effect of Noni Fruit Extract (Morinda citrifolia L.) in Citrate- Yolk Diluent on The Boer Goat Spermatozoa Motility Stored at Temperature $5^{\circ} \mathrm{C}$
}

\author{
Cut N. Thasmi ${ }^{1}$, Muhammad Ikhsanuddin ${ }^{2}$, Hamdan Hamdan $^{1}$, Dasrul Dasrul ${ }^{1}$, Muhammad N. Salim ${ }^{3}$, and Al Azhar ${ }^{4}$ \\ ${ }^{1}$ Laboratory of Reproduction, Faculty of Veterinary Medicine, Universitas Syiah Kuala, Banda Aceh 23111, Indonesia \\ ${ }^{2}$ Study Program of Veterinary Education,Faculty of Veterinary Medicine, Universitas Syiah Kuala, Banda Aceh 23111, Indonesia \\ ${ }^{3}$ Laboratory of Pathology, Faculty of Veterinary Medicine, Universitas Syiah Kuala, Banda Aceh 23111, Indonesia. \\ ${ }^{4}$ Laboratory of the Faculty of Veterinary Medicine, Universitas Syiah Kuala, Banda Aceh 23111, Indonesia
}

\begin{abstract}
This study was conducted to determine the best level of noni fruit extract (Morinda citrifolia $\mathrm{L}$ ) addition into citrate-yolk extender on the motility of boer goats spermatozoa preserved at $5^{\circ} \mathrm{C}$. Semen was collected using artificial vagina once a week from 1 healthy male aged \pm 7 years,. The treatments were citrateyolk administrated by noni fruit extracts (P0: 0 g, P1: 2 g/100 ml, P2: 4 g/100 ml, P3: 6 g/100 ml, P4: 8 g/100 $\mathrm{ml}$ ) and stored at $5^{\circ} \mathrm{C}$. The parameters were motility spermatozoa percentage. Observations were made at 2 , $24,48,7296$ hours after refrigeration. The data obtained was analyzed with split plot analysis of variance (ANOVA) follo wed by Duncan test. The average percentage of sperm motility after refrigated for 96 hours in the groups P0; P1; P2; P3; and P4 respectively was $24,20 \pm 0,83 \% ; 34,40 \pm 4,61 \% ; 40,20 \pm 5,71 \%$; $14,64 \pm 21,63 \%$; and $9,54 \pm 21,33 \%$. The results showed that giving of noni fruit extract significantly affected $(\mathrm{P}<0,05)$ on the percentage of motility spermatozoa of boer goat after refrigeration. It was concluded that the administration of $4 \mathrm{~g} / 100 \mathrm{ml}$ noni fruit extract in citrate- yolk after stored at $5^{\circ} \mathrm{C}$ resulted a greater sperm motility for up to 96 hours.
\end{abstract}

Keywords: boer goat, motility spermatozoa, extender and noni fruit extract.

\section{Introduction}

Boer goats are a superior breed of goats originating from South Africa, including the type of goat with a fairly high percentage of carcasses reaching 48-60\% [1]. One of the efforts that is quite effective and efficient in improving genetic quality and population of goats, needs to be supported by the existence of reproductive technology in the form of Artificial Insemination (AI) program.

. One of the technologies integrated with $\mathrm{AI}$ is semen processing technology [2,3]. With semen processing technology there are still many obstacles encountered, especially regarding the use of the right type of diluent, which is able to maintain the quality of semen during dilution and insemination in females [4]. One of the diluents that can be used to semen goat is egg yolk citrate. Citrate functions as a buffer that acts to protect spermatozoa from the $\mathrm{pH}$ changes which can damage spermatozoa cells [5]. The egg yolks contain lecithin and lipoprotein that prevent the occurrence of cold shock due to sudden temperature drops [6].

During the processing and storage of semen at cold temperatures, spermatozoa will undergo a metabolic process to maintain their life. In addition to producing energy, semen metabolism also produces free radicals that can damage the spermatozoa plasma membrane through lipid peroxidation reaction [7].

According to Agarwal et al. [8], free radicals can affect the motility and viability of spermatozoa. As a result spermatozoa will move slowly and even die so they are unable to fertilize an $\operatorname{egg}[11]$. In this case, an antioxidant as a "predator" of free radicals is needed to protect spermatozoa in diluents, such as by using fruits extract.

Nowadays many people use fruits as a source of antioxidants for semen including melon juice [9] carrot juice [10] figs, red dragon fruit [11] and dates [12]. The other fruits that can be used as semen diluents are noni plant. Noni fruit contains secondary metabolite compounds that are very beneficial for health, the nutritional content is also diverse as vitamins $\mathrm{A}, \mathrm{C}$, niacin, thiamine and riboflavin, and minerals such as iron, calcium, sodium, and potassium [13]. Noni fruit can also be used as an additional ingredient in the diluent because it contains many antioxidants such as linoleic acid, $\beta$ carotene, vitamin $\mathrm{C}$, flavonoids, caprylic acid, xeronin, and proxeronin which can function to ward off free radicals $[14,24]$.

Sabile et al. [3] states that Vitamin C has the ability to increase the stability of the plasma membrane protective tissue against lipid peroxidation, so as to maintain the

\footnotetext{
Corresponding author: cutnilathasmi@unsyiah.ac.id/cutnilathasmi@gmail.com
} 
quality and quantity of cement. This is consistent with the research of Isnaini and Nuryadi [15], reporting that goat semen diluted with noni fruit extract in concentration $10 \%$ in tris diluent was able to maintain the quality of PE goat spermatozoa during cooling process. Furthermore, Sabile et al. [3].reported that administration of $0.02 \mathrm{~g} / \mathrm{ml}$ noni fruit extract can maintain spermatozoa motility in the Bali cow's semen

Based on this, the authors are interested in further studying about the benefits of giving Noni (Morinda citrifolia L.) extracts in egg yolk citric diluents as an alternative diluents and how much the dose of noni extract that can increase the motility of boer goat spermatozoa stored at $5^{\circ} \mathrm{C}$.

\section{Materials and Methods}

\subsection{Place and Time}

This research was conducted at the Experimental Animal Laboratory and the Reproduction Laboratory of the Faculty of Veterinary Medicine at Syiah Kuala University to test the quality of spermatozoa. The making of noni fruit extract was carried out at the Pharmacology Laboratory of the Faculty of Veterinary Medicine at Syiah Kuala University. This research was conducted in January to February 2019.

\subsection{Methods}

In this study used 1 adult male goat \pm 7 years old, with a minimum semen sample having an individual motility of $\geq 70 \%$ and a minimum mass motility $(++)$ with a concentration of $500 \times 10^{6}$ per $\mathrm{ml}$. This research was an experimental laboratory study using a split plot variant analysis design consisting of 5 treatments with 5 replications each, with egg yolk citric diluents and noni extract added $0,2,4,6$, and $8 \mathrm{~g}$.

\subsection{Procedure}

\subsubsection{Noni FruIt Extraction}

The process of making noni fruit extract is based on what was stated by Sabile et al. [3] modified by post-harvest noni fruit cleaned and thinly cut. Noni fruit simplisia is produced as much as $500 \mathrm{~g}$ to be macerated. Extracts that resulting from maceration or filtrate produced accommodated into one and evaporated, to separate the solvent so that the thick extract of noni fruit (Morinda citrifolia L) is obtained.

\subsubsection{Citrate Yolk}

Furthermore, the citrate solution was mixed with egg yolk in a ratio of 4: 1 into a $100 \mathrm{ml}$ erlenmeyer. $1000 \mathrm{IU} / \mathrm{ml}$ penicillin antibiotics and $1 \mathrm{mg} / \mathrm{ml}$ streptomycin are also added to the diluents and then homogenized.

\subsubsection{Fresh Sement Quality Check}

Examination of semen immediately after collection is done macroscopically (volume, color, odor, $\mathrm{pH}$, and viscosity) and microscopically (concentration of motility, viability, and spermatozoa abnormalities). Semen which has a minimum mass movement ++ and motility of life $\geq$ $70 \%$, abnormality $<20 \%$ which is used as a sample [16].

\subsubsection{Making Semen Dilution}

In each treatment, the diluent is made as much as $100 \mathrm{ml}$. In P0 (control), the ingredients used as diluent was only egg yolks. In P1 the egg yolk citric diluent is added 2 $\mathrm{g} / 100 \mathrm{ml}$ of noni fruit extract; P2 egg yolk citric diluents added $4 \mathrm{~g} / 100 \mathrm{ml}$ of noni fruit extract; P3 the egg yolk citric diluent is added $6 \mathrm{~g} / 100 \mathrm{ml}$ of noni fruit extract; and $\mathrm{P} 4$ the egg yolk citric diluent was added $8 \mathrm{~g} / 100 \mathrm{ml}$ of noni fruit extract.

\subsubsection{Semen Dilution}

The volume of semen diluent is calculated according to the formula:

The amount of diluent $=\frac{\mathrm{SV} \times \mathrm{Sp} . \mathrm{C} \times \mathrm{M}}{\mathrm{Sp} . \mathrm{C} \text { desired } / \mathrm{ml} \text {. }} \times$ straw Vol

Ket: $\mathrm{SV}=$ Semen Volume; Sp. $\mathrm{C}=$ Spermatozoa Concentration; $\mathrm{M}=$ Motilitas.

\subsubsection{Semen Cooling}

Semen that has been diluted by the diluents of each treatment group is put into an Eppendorf tube $(1.5 \mathrm{ml})$, then stored in a refrigerator at $5^{\circ} \mathrm{C}$.

\subsubsection{Evaluation of Spermatozoa Motility}

The percentage of motility of goat spermatozoa was done by observing once in a day for 5 days of storage in a refrigerator with a temperature of $5^{\circ} \mathrm{C}$. Furthermore the motility of spermatozoa are counted as a percent (\%).

\subsection{Data analysis}

The data of spermatozoa motility obtained were analyzed using analysis of variance (ANOVA) split-plot patterns. The analysis was carried out with the help of the SPSS 23.0 for Windows program.

\section{Results and Discussions}

\subsection{Quality of Fresh Cement of Boer Goat}

As a basis for determining which cement is suitable for further processing can be seen from the results of evaluating the quality of fresh cement. There are several requirements for the fresh semen quality : volume, color, consistency, odor, semen $\mathrm{pH}$, mass movements, individual movements, viability, and spermatozoa abnormalities. The observation results of about characteristics of fresh semen of Boer goats after collection can be seen in Table 1 .

The volume of fresh semen Boer goats obtained from five ejaculates, in this study the average volume of semen was $1.1 \pm 0.65 \mathrm{ml} /$ ejaculation. The value of cement volume in this study is lower when compared with the results reported by Pranintya (2017) $2.38 \pm 0.07 \mathrm{ml}$, but relatively higher than the volume of cement reported. 
Table 1. Average ( \pm SD) characteristics of fresh semen of boer goats after collection.

\begin{tabular}{ll}
\hline Parameter & Observation \\
\hline Volume (ml) & $1,1 \pm 0,65$ \\
Color & Creamy-white \\
Consistency & Medium-thick \\
Odor & Typical \\
$\mathrm{pH}$ & $6,44 \pm 0,15$ \\
Mass Movement & $++/+++$ \\
Motility $(\%)$ & $77.54 \pm 3.97$ \\
Concentration $\left(10^{9} / \mathrm{ml}\right)$ & $2.22 \pm 0.13$ \\
Viability $(\%)$ & $87.68 \pm 1.15$ \\
Abnormality $(\%)$ & $7.8 \pm 1.48$ \\
\hline
\end{tabular}

The color of semen obtained in this study was white or creamy white, and the consistency ranged from moderate to thick. These results are consistent with those reported by Suyadi et al. [17], Ax et al. [18] and Isnaini [15] that the color of semen in goats is milky white to creamy.

Boer goat semen accommodated in this study has a distinctive odor of cement. The characteristic odor indicates that semen is normal and not indicated by microorganisms (19). The average concentration of spermatozoa obtained from five Boer goat ejaculates were $2.22 \pm 0.13 \times 109 / \mathrm{ml}$. These results are following the spermatozoa concentration range for each $\mathrm{ml}$ of semen which reported by Suyadi et al. [17], that the concentration of Boer goat semen maintained in Malang (Indonesia) was 2.67x109/ml.

The average of $\mathrm{pH}$ level of fresh semen of Boer goats obtained in this study was $6.44 \pm 0.15$. The $\mathrm{pH}$ value of the Boer goat is quite normal because the normal $\mathrm{pH}$ range of the semen of the goat or sheep is 5.9-7.3 (20). The average mass motility obtained from the fresh semen of Boer goats recorded an average positive score $(++/+++)$. This is indicated by black waves that are not so dark and thick but the movement is still fast. [21]. explained that the mass movement gives an idea of the spermatozoa's motion if it gets thicker and bigger waves and its movement shows the quality of semen better.

The percentage of motility and viability of Boer goat fresh semen obtained was $77.54 \pm 3.97 \%$ and $87.68 \pm$ $1.15 \%$. These results are consistent with those reported by Rohman (2018) that motility is $76.67 \pm 2.89 \%$ and viability is $82.41 \pm 1.59 \%$. The high level of motility determines marital success both naturally and in the IB program .

The abnormalities percentage of fresh semen obtained from the results of this study were $7.8 \pm 1.48 \%$. This value is higher than the results reported by Rosmaidar et al. [22](6.38 $\pm 1.96 \%)$ using the electroejaculator. The difference in the mean value was influenced because during the process of spermatozoa formation in the process of spermatogenesis and because the process of spermatozoa travels through the channels of male genital organs [6].

\subsection{The Percentage of Individual Motility of Spermatozoa Boer Goats After Cooling Process}

Based on the results of this study (Table 2), it can be seen that the percentage of Boer goat spermatozoa motility decreases with the duration of storage time. The decrease in spermatozoa motility percentage occurred in the control group (P0) and followed by the treatment groups P1, P2, P3, and P4. Observations at 12, 24, 48, 72 , and 96 hours showed the highest percentage of spermatozoa motility was in the P2 treatment group while the lowest yield was in P4.

Table 2. Mean $( \pm$ SD) percentage of motility of individual spermatozoa of boer goats after cooling

\begin{tabular}{cccccc}
\hline \multirow{2}{*}{$\begin{array}{c}\text { Observa- } \\
\text { tion Time }\end{array}$} & \multicolumn{5}{c}{ Individal Motility of Spermatozoa (\%) } \\
\cline { 2 - 6 } & P0 & P1 & P2 & P3 & P4 \\
\hline 2 Hour & $80,06 \pm 5,14^{\mathrm{a}}$ & $79,56 \pm 4,78^{\mathrm{a}}$ & $81,52 \pm 4,66^{\mathrm{a}}$ & $74,58 \pm 3,14^{\mathrm{a}}$ & $70,76 \pm 1,13^{\mathrm{a}}$ \\
\hline 24 Hour & $76,02 \pm 3,90^{\mathrm{a}}$ & $70,28 \pm 11,85^{\mathrm{ab}}$ & $76,54 \pm 3,76^{\mathrm{ab}}$ & $68,52 \pm 2,10^{\mathrm{a}}$ & $63,80 \pm 4,66^{\mathrm{ab}}$ \\
\hline 48 Hour & $70,52 \pm 6,22^{\mathrm{a}}$ & $66,60 \pm 11,49^{\mathrm{b}}$ & $67,34 \pm 8,72^{\mathrm{b}}$ & $63,28 \pm 5,80^{\mathrm{a}}$ & $54,04 \pm 9,12^{\mathrm{b}}$ \\
\hline 72 Hour & $55,00 \pm 13,85^{\mathrm{b}}$ & $45,12 \pm 10,49^{\mathrm{c}}$ & $49,08 \pm 14,00^{\mathrm{c}}$ & $37,00 \pm 4,47^{\mathrm{b}}$ & $32,60 \pm 2,50^{\mathrm{c}}$ \\
\hline 96 Hour & $24,20 \pm 0,83^{\mathrm{c}}$ & $34,40 \pm 4,61^{\mathrm{c}}$ & $40,20 \pm 5,71^{\mathrm{c}}$ & $14,64 \pm 21,63^{\mathrm{c}}$ & $9,54 \pm 21,33^{\mathrm{d}}$ \\
\hline
\end{tabular}

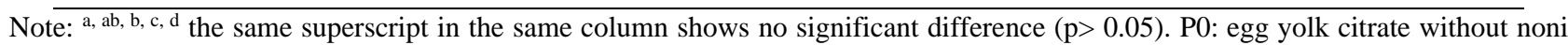
extract (control); P1: egg yolk citrate $+2 \mathrm{~g} / 100 \mathrm{ml}$ noni fruit extract; $\mathrm{P}$ : egg yolk citrate $+4 \mathrm{~g} / 100 \mathrm{ml}$ noni fruit extract; $\mathrm{P}$ : egg yolk citrate $+6 \mathrm{~g} / 100 \mathrm{ml}$ noni fruit extract; $\mathrm{P} 4$ : Egg yolk citrate $+8 \mathrm{~g} / 100 \mathrm{ml}$ Noni fruit extract.

Based on the analysis of variance (ANOVA) splitplot patterns on the percentage of spermatozoa motility showed a significant differences $(\mathrm{p}<0.05)$ on the dose of diluent and storage time but there was no interaction between the two. This shows that the administration of noni fruit extract in egg yolk citrate media can affect the motility of Boer goat spermatozoa during the storage process at $5^{\circ} \mathrm{C}$. This situation also shows that the administration of noni fruit extract in egg yolk citrate media can affect the metabolism and physiology of spermatozoa.

Based on this study the percentage of spermatozoa motility decreased along with the shelf life. According to Rosmaidar et al. [22] decreased the percentage of Boer goat spermatozoa motility with the longer cooling time, the lower the percentage of motility obtained. This is thought to reduce the availability of energy in retailers, the more aging of spermatozoa and the increasing $\mathrm{pH}$ of 
semen and the increasing number of spermatozoa that are damaged and die due to cooling.

The results also showed that the effect of noni fruit extract in egg yolk citric diluents on the percentage of spermatozoa motility differed between observations. At the observation of 2 to 96 hours spermatozoa, motility in the P2, treatment group was higher than P1, P3, P4. Semen in the egg yolk citric diluent with the addition of 4 g/ $100 \mathrm{ml}$ noni fruit extract can maintain spermatozoa until the $96^{\text {th }}$ hour after storage and shows the percentage of the progressive movement is still $40 \%$ (suitable for insemination).

Egg yolk diluent with the addition of $2 \mathrm{~g} / 100 \mathrm{ml}$ Noni fruit extract (P1) spermatozoa lasted until 72 hours after cooling, relatively similar to the control group (P0). Furthermore, in egg yolk citric diluents with the addition of $6 \mathrm{~g} / 100 \mathrm{ml}$ noni fruit extract and $8 \mathrm{~g} / 100 \mathrm{ml}$ lasted until the 48th hour after cooling. The results of this study are following what was reported by Mujadi [23] that goat semen after dilution stored at $4-5^{\circ} \mathrm{C}$ will experience a gradual decrease in motility throughout storage time.

The results showed that from 2 to 96 hours of observation, the percentage of spermatozoa motility in the P2 treatment group was seen to be able to maintain spermatozoa motility up to 96 hours after cooling. The high percentage of spermatozoa motility in this treatment group is due to the dilution of the solution which can maintain the $\mathrm{pH}$ of the solution without changing the levels ofideal for the activity and life of spermatozoa in the diluent solution. The results of the experiment also indicated that the motility of spermatozoa through increasing the dose of noni fruit extract at the level of 6 $\mathrm{g} / 100 \mathrm{ml}$ and $8 \mathrm{~g} / 100 \mathrm{ml}$ in egg yolk citric diluent tended to decrease the motility percentage of individual spermatozoa.

Noni fruit extract contains elements that are able to maintain spermatozoa from damage during storage at $5^{\circ} \mathrm{C}$. One of these elements includes carbohydrates and antioxidants such as vitamin $\mathrm{C}$, phenolic, flavonoids, $\beta$ carotene. Carbohydrates contained in noni fruit can be metabolized into energy in the form of ATP..

\section{Conclusions}

The administration of $4 \mathrm{~g} / 100 \mathrm{ml}$ Noni fruit extract in egg yolk citrate diluent $(\mathrm{P} 2)$ can maintain the best motility percentage of individual Boer goat spermatozoa after $5^{\circ} \mathrm{C}$ storage for up to 96 hours of storage.

\section{References}

1. Campbell, Q.P. - Performance Testing And Adaptability Of Boer Goat. Boer goat news. 9. 1990.

2. Nurrani. Pengaruh Penambahan Ekstrak Bawang Merah (Alium cepa) di Dalam Pengencer Tris Kuning Telur Itik Terhadap Kualitas Spermatozoa Kerbau Lumpur Pada Penyimpanan $5^{\circ}$ C. Publikasi Ilmiah. Fakultas Peternakan Universitas Mataram, Mataram. 2018

3. Sabile, S., Toleng, A.L., Yusuf, M., Pengaruh penambahan ekstrak buah mengkudu (Morinda citrifolia Linn) dalam pengencer terhadap
4. Hafez, E.S.E., and Hafez, B. Semen evaluation. In reproduction in farm animals. 7 th edition. Lippincott wiliams and wilkins. Maryland, USA. 363-375. 2000.

5. Evans, G., and Maxwell, W.M.C. Salamon's Artificial Insemination Of Sheep And Goats. Butterworths, London. 1987

6. Toelihere, M. R. Inseminasi Buatan pada Ternak. Angkasa. Bandung. 1993.

7. Zaniboni, L., Rizzi, R., and Cerolini, S. Combined effect of DHA and $\alpha$ - tocopherol enrichment on sperm quality and fertility in the Turkey. Theriogenology, 2006;65(1): 1813-1827.

8. Agarwal, A., Prabakaran, S., and Said, T. . Prevention of oxidative stress injury to sperm. $J$. Adrol, 2005;26: 654660.

9. Herdis, Yulnawati dan Setiadi, M.A. Pemanfaatan sari buah melon sebagai media pengencer semen cair alternatif spermatozoa domba garut. Jurnal Sains dan Teknologi Indonesia, 2003;5:126-131.

10. Parera, F., Prihatiny, Z., Souhoka, D.Fet al.: Pemanfaatan sari wortel sebagai pengencer alternatif spermatozoa epididimis sapi bali. J.Indon.Trop.Anim.Agric, 2009;34(1): 50-57.

11. Munawarah. Pemanfaatan ekstrak buah naga (Hylocereus undatus) untuk pengawetan spermatozoa kambing peranakan boer pada suhu $5^{\circ} \mathrm{C}$. Publikasi Ilmiah. Universitas Mataram. 2014.

12. Malik, A., Yayan, Zakir, M.I., et al.: Effects of addition of juice date palm to the extender on the semen qualities of frozen thawed in bull spermatozoa. Global Veterinaria, 16(1): 100-104.

13. Winarti, $\mathrm{C}$. Peluang pengembangan minuman fungsional dari buah mengkudu (Morinda citrifolia L.). Jurnal Litbang Pertanian, 2005;24(4):149-155.

14. Andarwulan, N. . Kimia vitamin. CV. Rajawali, Jakarta. 1992.

15. Isnaini, N. Peranan trehalosa dalam pendinginan dan pembekuan semen kambing Boer. Disertasi. Program Studi Ilmu Pertanian Universitas Brawijaya, Malang. 2006.

16. Wahyuni, S.T., Dasrul, Hamdan, et al.: Pengaruh penambahan ekstrak kulit buah naga merah (Hylocereus polyrhizus) dalam media sitrat kuning telur terhadap daya tahan hidup spermatozoa Sapi Aceh yang disimpan pada suhu 40C. JIMVET. 2018;2(1): 102-109.

17. Suyadi, Susilawati, T., dan Isnaini, N. Uji pembekuan semen kambing Boer. Laporan Penelitian. Kerjasama Dinas Pertenakan- Fakultas Peternakan Universitas Brawijaya, Malang. 2004.

18. Ax, R.L., Dally, M.R., Didion, B.A., Semen Evaluation. Lippincott \& Wilkins, Philadelphia. 2000.

19. Suyadi, Rachmawati, A., and Iswanto, NEffect of $\alpha$ tocopherol in tris-aminomethane-egg yolk on the semen quality cold stroge in boer goats. Jurnal Ilmu Ilmu Peternakan, 2012;22(3): 1-8.

20. Garner, D.L., and Hafez, E.S.E. Spermatozoa And Seminal Plasma. Lippincott \& Wilkins, Philadelphia. 2000

21. Rohman, D.F. Pengaruh sari bawang putih (Allium sativum L.) dalam pengencer andromed terhadap kualitas semen kambing boer selama penyimpanan suhu kamar. Skripsi. Fakultas Peternakan Universitas Brawijaya, Malang. 2018

22. Rosmaidar, Dasrul, dan Lubis, T.M. Pengaruh penambahan sari buah tomat dalam media pengencer 
terhadap motilitas dan viabilitas spermatozoa kambing boer yang disimpan pada suhu 3-5 ${ }^{\circ} \mathrm{C}$. Jurnal Ilmiah Peternakan, 2013;1(1): 7-17.

23. Mujadi. Kualitas Semen kambing Peranakan Ettawah yang diencerkan dengan susu segar kambing dengan kuning telur pada penyimpanan suhu 40C. Laporan Penelitian. Fakultas Peternakan Universitas Brawijaya Malang. 2003.
24. Windarti, I., Aditya, P.B., dan Susianti. Buah mengkudu (Morinda citrifolia) sebagai penghambat aterosklerosis. Jurnal Majority, 2014;3(3): 18-26. 